\title{
The Monetary Economy in Buddha Period (Based On the Comparative Analysis of Literary and Archaeological Sources)
}

\author{
${ }^{1}$ Dr. Anuradha Singh, ${ }^{2}$ Dr. Abhay Kumar \\ ${ }^{I}$ Assistant Professor, Department of History, Faculty of Social Sciences, Banaras Hindu University, \\ Varanasi-221005, U.P., India. \\ ${ }^{2}$ Assistant Professor Department of History,School of Social Sciences, Guru Ghasidas Central \\ University Bilaspur-495009, C.G., India.
}

\begin{abstract}
Archaeology reveals that the sixth BC era was the time of secondary civilization. Many cities as Shravasti, Saket, Ayodhya, Champa, Rajgriha, Kosambi and Varanasi described in Pali literature is indicative of materialistic prosperity and rich town culture. These northeastern towns of India are connected by highways to Takkasila $\bar{a}$ in north, Pratishtha in south, Mrigukachha in west, Tamralipti in east and of central Kanyakubza, Ujjayini, Mathura, Sankashya and many others places. These cities were inhabited by northern black glittering earthen-pot culture. Peoples of this culture widely use iron make weapons and stricken coins. These materialistic and archaeological relics exhibit their economic strength. Artisans and businessmen were doing trading by forming union in cities. We came to know the eighteen categories of artisans. Contribution of stricken coins was very important in trading and buying-selling by these categories. By the circulation of stricken coins, trading was promoted significantly and trading becomes simplified. Various proofs of currency circulation is found in Pali scriptures and it also came to knowledge that the payments of salaries and buying was made by coins. The Buddha monks and nuns do not accept donation in form of currency. In this way it is clear from the above descriptions that the circulation of currency undoubtedly present in the time of Buddha, which is also described in Buddha literature and also confirmed with archaeological proofs in this Reseach Paper.
\end{abstract}

Development of an urban civilization was started in sixth century BC parallel to the ancient Indian rural civilization. The repeated description of cities like Shravasti, Saket, Ayodhya, Champa, Rajgriha, Kosambi and Varanasi in Buddha literature is indicative of materialistic prosperity and rich town culture. These northeastern towns of India are connected by highways to Takkasila in north, Pratishtha in south, Mrigukachha in west, Tamralipti in east and of central Kanyakubza, Ujjayini, Mathura, Sankashya and many others places. The description of river and sea merchant is found in Jätakas and big and small group of businessmen travel from one place to another. In this context, description of major affluent persons and their limitless wealth, their ample donation ${ }^{1}$ to Buddha organizations, vogue of coins to fulfill the necessities of exchange for religious rites are indicative of a developed financial culture. It's remarkable that in the literatures of Buddha, along with the prevalence of currency, barter system was also in use. For merchandising, generally coins were used in the society. ${ }^{2}$

The Buddha monks were neither collect nor touch the money, preferentially they adopt the mode of bartering. Till the time of Jätakas, one magnitude of rice was in vogue for the bartering. ${ }^{3}$ But in the period of Buddha, firm evidences reveal towards the prevalence of coins and many times it appeared that the cost of many items were decided in form of coins. ${ }^{4}$ The nomenclature of these coins were, Nikkh or Nishk; Kahapan or Karshapan or Suvarna ${ }^{5}$, Kans, Paad, Mass or Masak ${ }^{6}$ and Kankanik ${ }^{7}$. Nishka was a golden coin, initially which was used in the form of an ornament. The name of 'Suvarna' exhibit that it was a gold coin. Probably it was also known as Hiranya. Description of Hiranya is found in the Petvathhu. ${ }^{8}$ Though, molded coins are found in the reign of Prasenjit, Bimbisar and Ajatshatru, but it is amazing. In the Atthakatha of Vinay-Pitak, in the lifetime of God Buddha, means in the reign of king Bimbisar and Ajatshatru, it was said focusing on the in vogue currency system- tada rajgahe visatimasko kahapano hoti tasma panchmasko paado. eiten lakkhnen labbajanpadesu kahapanasya chatuthhon bhago pado ti veditabbo. ${ }^{9}$ Its meaning is that at that time in the royal mansion one kahapan was equivalent to 20 mase (masak), while one pad was equivalent to five mase (masak). It exhibits that at that time in all the districts, one-fourth part of the kahapan was told as paad. It indicates that according to the in vogue currency in the lifetime of God Buddha, one paad was equivalent to five maase and one kahapan was equivalent to one kahapan. In this way, one kahapan was equivalent to 20 masak. ${ }^{10}$ It is notable that at that time 
masak or masa was weighing of the weights of metals, it prevails at present also in our country and for the coins of different metals, different mason (maashon) were fixed. It is evinced from the vinaypitak that during the reign of Ajatshatru or Bimbisar, five mase was equivalent to one paad and one nishk was equivalent to five suvarnas.

The most circulated coin in Buddha period was told Kahapan, but that's value could not be decided till today. But according to Atthakatha of Vinaypitak the value of one Kahapan was equivalent to twenty mase. ${ }^{12}$ But this annotate of Buddhaghosh was written after about one thousand years in the period of Gupta reign and due to this, we could not reach on any definite conclusion. According to Buddhaghosh ${ }^{13}$ Kahapan was coin made of silver. It is evinced from the Jataka that the costs of so many items were usually being evaluated in Kahapans. For example, the cost of a pair of bulls was twenty-four Kahapans ${ }^{14}$, a donkey in eight Kahapans $s^{15}$, weight of one pack in one Masak of one thousand ${ }^{16}$, one horse of a good race worth six Kahapans ${ }^{17}$, precious dress in Kashi worth one lakh Kahapans ${ }^{18}$ and the wage of a daily wage labour was one Masak or Ardha Masak. ${ }^{19}$

Acharya Buddhaghosh has used the word 'Old Neel Kahapan' for the Kahapan coins of Buddha period. ${ }^{20}$ In Atthasalini ${ }^{21}$, Acharya Buddhaghosh has described Kahapans of white (Pander) colour having big size (Puthul) and quadrangular (Chaturssa) size. From the white colour (Pander), it proves that they were made of silver. In an another chapter of Atthasalini, defining the word 'Rajat', Buddhaghoshacharya has told it Kahapan- 'Rajat Vucchati Kahapano. ${ }^{22}$ It clearly indicate that the Kahapans were usually made of silver. It is notable that so many Kahapans of silver were found in later Maurya period. Though on the basis of Pali literature, it is proved that the Kahapans were made of silver, but it is also confirmed that some Kahapans made of copper were found in the later Maurya period. Therefore, we may assume that in the period of Buddha, Kahapans were made of copper and silver both metals. It is remarkable that besides Kahapan, Ardhakahapan, Paad Kahapan, Masak, Ardha Masak and Kakanika coins were also in use. Perhaps, the Kakanika was of least denomination at that time. By the affirmations of Atthasalini, we know that the Masak coins were also being made of copper, wood and shellac.

Apart from copper (lauh) and silver (chandi) the golden currencies were also in vogue in Buddha period. The golden currencies were known as Hiranya (Hiranj), to whose we may tell Asharfi. Anathpindak has purchased the Jetwan garden by piling of this Hiranyas. ${ }^{24}$ In Buddha period, the biggest golden coin was known as Nikkha (Nishk) and the weight of that become 25 dharana or approximately 10 ounce..$^{25}$ In context of a simile in Anguttarnikaya Nekhaon Jambondassev (like golden Nishk) is descripted. ${ }^{26}$ Since the Nishk was very precious, so it was not used in day-to-day life. Perhaps by this reason its archaeological proof could not be found till now. To maintain the civic economy and development of trading, a large number of currencies would be needed in that time and along with the golden currency silver and copper currencies would be came in existence. In this period abundance of silver and copper currencies is corroborated by literary and archaeological proofs. ${ }^{27}$

Various descriptions of Kahapan and its subdivisions are found in the Buddha literature- Vinaypitak, Anguttnikaya and Majjhimnikaya. Daily donation of 500 Kahapans by the king of Anga is described in Majjhimnikaya. Though, these scriptures could not be placed before the Maurya period, yet the socio-economic status of later Maurya period is also known by the descriptions. ${ }^{26}$ The study of Jataka reveals that the usage of Kahapan was done by all classes of society for their daily requirements. Kahapan was a part of common peoples. Description of subdivisions of Kahapan as 1/2 (Aaddha Kahapan), 1/4 (Paad Kahapan), 1/8 (Dwimasak), $1 / 5$ (one Masak) are found many times. ${ }^{29}$ It is notable that its description is also found in commercial transactions. Undoubtedly the Karshapan was representing the stricken currencies ${ }^{30}$, whose weight was 32 Ratti means 56 Grain. Stricken currencies of similar weights are found from the various area of India during archaeological excavations.

Various currencies described in Buddhist literature are also indicative of the then religious and socioeconomic conditions. It is remarkable that the acceptance of currency by a Buddhist monk presumed a crime. It is referred in the Bhibkhunipattimo of Vinaypitak that if any Buddhist nun accepts coins of gold or silver, or deliver it, use it after collecting, then she will be assumed of religious transgression and she will be punished for this act. ${ }^{32}$ It is described in the Shaptshatik chapter of Vinaypitak that for the refinement of Buddha convent of Vajjiputtak of Vaishali, beneath the convent, in a bronze dish, Kahapan, Addha Kahapan, Paad Kahapan, two Masa demanded from devotees in form of donation. ${ }^{33}$ Descriptions are also found in the Chullavagga Jatak that the Buddha monks of Vaishali are motivating a person to donate Kahapan and Ardha Kahapan to Buddha convent. ${ }^{34}$ It is described in Vinaypitak that a Buddha nun hoarded Karshapan received from yeoman with a trader (Vanik), because of that she may purchase needful items without touching the Karshapan. ${ }^{35}$

The stamped sign of spine, altar, tree, umbrella, mound with wand; spine, horse, elephant, Capricorn, tri-gem, ashtar ( $\left.\mathrm{v}^{\prime} \mathrm{Vkj}\right)$, wheel etc. unbarred with semicircle found on the stricken currencies is of religious importance. The numismatists have identified the Karshapan as stricken currency. On the basis of stamped signs on stricken currency, historians have guessed that some signs are related with Buddha religion. The numismatists have accepted the signs of tri-gem and trikkeziz (fV Ddstht) and tri-gem as indicative of tri-gem, Buddha, religion and union of Buddha religion. The sign of Capricorn is assumed as the sign of happiness and 
prosperity also in Buddha religion, likewise Hinduism. It seems that the spine mound unbarred with semicircle is covered with kuchaka (dqpd). Here it is notable that the mound is an indication of final beatitude of Buddha. The Fushe has connected the ashtar wheel with the persuasion of preaching and sermons of Lord Buddha. Likewise sermons are also engraved on the terraces of Bharhut and Ranchi. According to Spooner the terrace tree is indicative of Bodhivriksha. ${ }^{37}$ Basak and Fushe has accepted that the spine sign is indicative of Godly mound. In opinion of Cunningham, Kuta surrounded by umbrella is mound.$^{38}$ In the Buddha literature elephant ${ }^{39}$ and horse ${ }^{40}$ are indicative of Buddha's birth and Mahabhinishkraman (egkfHkfu'Øe.k), respectively.

Donation of Karshapan for the religious acts is described many times in Buddha literature. It is described that Anathpindak, a merchant of Shravasti has purchased a garden from the prince Jeta and donated it to the Buddha union covering it by the quadrangular Karshapans. It is also confirmed by the engraved figures on the wrapper of Bharhut mound ${ }^{41}$ and engraved figures on the pillars of the Bodh Gaya's temple. ${ }^{42}$ An another archaeological proof is painted figure on earthenware found from the Kaushambi excavation ${ }^{43}$, where also stamping is present on quadrangular and rounded coins.

Along with religious importance, currency was also of socio-economic importance. The sixth century B.C. is indicative of major change in economy. Some other factors have also provided it strength and speed. For example widely use of iron, agriculture of sugarcane and cotton on wide area, evolution and development of different cities on middle-Ganges plain, much differentiation and constitution at stages of handicraft and in the last but not least speedy local and remote business activities, which is also confirmed by the search of stricken coins. The view of archaeology reflects that the making of northern black polished earthen-pot was started from the sixth century BC. These bright earthen pots were used for war and production both. ${ }^{44}$ According to Dr. P.L. Gupta, the Karshapan currency my be came into existence for the trading of agricultural produce. ${ }^{45}$ In Mahavagga, it is described that the house of Mendak was filled with grains due to developed agri-practices and his wife gave Kahapan to agricultural labourers to pay their wages. ${ }^{46}$ In Vinaypitak, it is described that a prostitute named Ambpani (Amrapali) charges fifty Kahapan for a night and her competitor Shalavati charges two-times money from the citizens of Vaishali. ${ }^{47}$ Some crooked and fraudulent ascetics were also present in the society. In a novel of Kuhak Jatak ${ }^{48}$ story of such a fraudulent ascetic is described who grabbed nine Nishka of a family man after taking him in faith. Examples of social-crimes are also available in Jatakas. Imposition of twenty-four Karshapan fine for stealing a pair of ox by a person, and fine of one thousand Karshapan for cracking the leg of a horse by the ruler of Benaras is described in Gamani Chhanad Jatak. ${ }^{49}$ In the Bhuridatt Jatak, the income of a snake-charmer is told hundred Nishk per day, which seems a hyperbole. Paying one Kakani by rural boys to a labour for organizing magic-show is described in Salittak Jatak. ${ }^{50}$ Some descriptions about earning of 200 to 400 percent income by businessmen are also found in Jataka, it evinced that open plundering was also exist in the time Jataka. One such a story is also present in Jataka that describes 20 percent profit in business, in which expenses were noted as 1000 Karshapan for transportation, unloading and sweets distribution among security persons and gatekeepers. ${ }^{51}$ The royal officers, assigned for deciding the costs of different goods were involved in taking bribes.

In this way it is clear from the above descriptions that the circulation of currency undoubtedly present in the time of Buddha, which is also described in Buddha literature and also confirmed with archaeological proofs. For the selling and buying of goods, barter and currency both systems were existed. What was the materialistic lifestyle of north-Indian region, particularly in Uttar Pradesh, its hint came to knowledge by the archaeological proofs as well as by the studies of Pali literatures. Archaeology reveals that the sixth BC era was the time of secondary civilization. Many cities described in Pali literature as Kosambi, Shravasti, Ayodhya, Kapilvastu, Varanasi, Rajgriha, Pataliputra, Champa, etc. were excavated. These cities were inhabited by northern black glittering earthen-pot culture. Peoples of this culture widely use iron make weapons and stricken coins. These materialistic and archaeological relics exhibit their economic strength. Artisans and businessmen were doing trading by forming union in cities. We came to know the eighteen categories of artisans. Contribution of stricken coins was very important in trading and buying-selling by these categories. By the circulation of stricken coins, trading was promoted significantly and trading becomes simplified. Various proofs of currency circulation is found in Pali scriptures and it also came to knowledge that the payments of salaries and buying was made by coins. The Buddha monks and nuns do not accept donation in form of currency. If they do so then, charged guilty and punished according to the rules of Buddha union. But some instances were found where the monks and nuns, denied to accept the currency and advice donors to give it to their close family men. The family men keep its proper accounting and on demand provide equivalent cost goods to them. By this activity, the rule of Buddha union does not violate. By this, it is clear that at the time of Buddha, the business was of high quality and developed economy was existed in the country which was mainly coin based. In this economy the peoples of higher and lower strata both were involved. 


\section{References}

[1] Sushil Kumar Shukla, Prachin Bharat mein daan ki sankalpana aur vyaohar, Banaras Hindu University, Unpublished research dissertation, Chapter-5, pp. 98-162.

[2] D.R. Bhandarkar, Lectures on Ancient India numismatics, 1921, p. 109.

[3] C.A.F. Cambridge History India, Volume-1, Cambridge, 1922, p. 217.

[4] Yatindranath Bose, Social and Rural Economy of Northern India, Volume-1, Second edition, Kolkata, 1957, pp. 15 and forth.

[5] Hindi translation of Jataka, Bhadant Anand Kauslyayan, in six volumes, Hindi Sahitya Sammelan Prayag, vikrami Samvat 2013, No. 540 .

[6] Ibid, No. 288.

[7] Ibid, No. 4.

[8] "Na hi Tatth Kasi Atthigorakh Ettan Na Vijjati, Vanijja Tadisi Natthi Hiryannen Kay Nishkayam”. Petavatthu, p. 3, Edited in Hindi by Rahul Sanskrityayan, Anand Kauslyayan and Jagadish Kashyap, Mahabodhi Society, Sarnath, 1937.

[9] 'Samantpasadika' Second Edition, p. 207, Reference of Vinaypitak, Edited by Buddhaghosh, J. Takakusu and S. Nagi, Palitechts Society London, 1924-37.

[10] Panini 'Ashtadhyayi' Sutra Panapaadmkhshtadyanta 4/1/34.

[11] C.A.F. Cambridge History India, Volume-1, Cambridge, 1922, p. 218

[12] 'Samantpasadika' Second Edition, p. 207.

[13] Rajat Vucchati Kahapano, do, p. 256.

[14] Jatak, Volume-2, pp. 305-06.

[15] Jatak, Volume-6, p. 343

[16] Jatak, Volume-3, p. 130.

[17] Jatak, Volume-1, p. 475.

[18] Jatak, Volume-2, p. 289.

[19] Jatak, Volume-3, p. 10.

[20] "So ch so poranasya neelkahapanassa vasen, na etresam rudradamkadinam". Samantpasadika Second Edition, p. 207.

[21] Atthasalini (3/622), V. Vapat and R. Wadekar, Pune 1942, p. 226

[22] Ibid, 41/54, p. 256.

[23] Ibid

[24] Vinaypitak, Edited and translated in Hindi by Monk Jagadish Kashyap, Mahabodhi Society, Sarnath, 1937, pp. 461-62.

[25] A.P. Buddhadutt Mahather, Concise Pali-English Dictionary, p. $131 \& 126$

[26] Anguttanikaya, Richard in Roman script, Edited by the Morris and E. Hardy, Palitechts Society London, Volume-1, 1885-1900, from the preamble.

[27] Rajwant Rao, Pradeep Rao, Prachin Bhartiya Mudrayen, Motilal Banarasi Das, Varanasi, 2001, p. 22.

[28] Ibid, p. 24

[29] Gangamal Jatak, Mehata R.N., Pre-Buddhist India, pp. 235-36.

[30] Alexander Cunningham, Coins of Ancient India, p. 33.

[31] Rajwant Rao, Pradeep Rao, Prachin Bhartiya Mudrayen, Motilal Banarasi Das, Varanasi, 2001, p. 24.

[32] Vinaypitak, Bhikkhunipatimokkha, p. 50.

[33] Vinaypitak, Saptashati-Skandhak, translated by Rahul Sanskrityayan, Mahabodhi Society, Sarnath, 1936, p. 548.

[34] Dethavasusi kahapanam addha pee paadam pee, Chullvagga, Jatak, Volume-2, p. 249.

[35] Amuksa ayye aavanikassa dhare kahapanam nikkhi pissami tato ye ichhyyasi tam, aaharyyeyyasim vinaypitak, Part-4, p. 249.

[36] Ja. Nu. So, Volume-38 (1977), pp. 23-24.

[37] Archaeological Survey of India, Annual Report, 1905-06, p. 151.

[38] Alexander Cunningham, Archaeological Survey of India, Annual Report, Volume-94, p. 186.

[39] Vasudeo Sharan Agrawal, Bhartiya Kala, Prithvi Prakashan, Varanasi (2000), pp. 103-04.

[40] Ibid., pp. 113-15. Deeghnikaya, Part-3, Edited in Hindi by Rahul Sanskrityayan and Jagadish Kashyap, Mahabodhi Society, Sarnath, 1936, pp. 58-63 \& 46-50.

[41] Alexander Cunningham, Stupa of Bharhut, London, 1871, p. 57

[42] Alexander Cunningham, Mahabodhi, London, p. 13.

[43] Malwa: A Survey, Edited by V.S. Vakankar, p. 71, G.R. Sharma, Exhibitions at Kosambi, Allahabad, 1960, pp. 20-21 (presently displayed in Allahabad Museum).

[44] Ramasharan Sharma, Prarambhik Bharat ka Aarthik aur Samajik Ithihas, Hindi Madhyam Karyanvaya, Nideshalaya, Delhi Vishwavidyalaya, 2000, p. 141.

[45] Parmeshwari Lal Gupta, Bharat ke purvakaleen sikke, Vishwavidyalaya Prakashan, Varanasi, 1996, p. 2.

[46] Mahavagga, Edited by W. Gaygar, Palitechts Society London, 1908, p. 255.

[47] Ambapali cha ganika anussanam panchasaya cha rati gachhati, Vinaypitak (8/1/1).

[48] Jatak, Volume-1, p. 375.

[49] Jatak, Volume-3, p. 5.

[50] Jatak, Volume-1, p. 149.

[51] Jatak, Volume-1, p. 109 \& Volume-4, p. 02.

[52] Jatak, Volume-1, p. 124. Edited by Thergatha, Pishel, Devanagari Edition, Nalanda, 1959, p. 212. 